\title{
Cogan Reese syndrome
}

\author{
Síndrome de Cogan Reese
}

Anelise de Medeiros Lago ${ }^{1}$, Ricardo Henrique Goulart Bittar ${ }^{1}$, Larissa Rossana Souza Stival ${ }^{1}$, João Jorge Nassaralla Junior ${ }^{2}$

\begin{abstract}
Study conducted to report a case of Cogan Reese syndrome. Female patient, 55 years old with diagnosis of Cogan Reese syndrome. Best visual acuity of 0.67 in the right eye and 0.2 in the left eye. By biomicroscopic examination there was no abnormalities in the right eye. In the left eye there were pigmented nodules on the anterior surface of the iris, corneal irregularities and iris hole (pseudopolycoria). The intraocular pressure was $18 \mathrm{mmHg}$ in the left eye and there was glaucomatous optic atrophy of the optic disk. The patient had been subjected to trabeculectomy three years ago. Recently medical treatment allowed the relative control of intraocular pressure. Gonioscopy revealed peripheral anterior synechiae. Corneal specular microscopy showed ICE-cells and low cell count. Glaucoma filtering surgery is usually successful when done early, but it may fail due to endothelialization of the fistula by the abnormal corneal endothelium. Medical treatment was effective despite a fail trabeculectomy.
\end{abstract}

Keywords: Glaucoma; Corneal dieseases/diagnosis; Iris dieseases/pathology; Endothelium, corneal/pathology; Syndrome; Case reports

\section{RESUMO}

Estudo realizado para descrever um caso da síndrome de Cogan Reese. Paciente do sexo feminino, 55 anos, com diagnóstico de síndrome de Cogan Reese. Melhor acuidade visual de 0,67 em olho direito e 0,2 em olho esquerdo. Pelo exame biomicroscópico não se detectou anormalidades no olho direito. No olho esquerdo haviam nódulos pigmentados na superfície anterior da íris, irregularidades corneanas e buraco iriano (pseudopolicoria). A pressão intra-ocular era $18 \mathrm{mmHg}$ no olho esquerdo e havia atrofia óptica glaucomatosa no disco óptico. A paciente havia sido submetida à trabeculectomia três anos atrás. Recentemente o tratamento medicamentoso possibilitou o controle relativo da pressão intraocular. Gonioscopia revelou sinéquias anteriores periféricas. A microscopia especular eletrônica mostrou ICE-cells e baixa contagem de células. A cirurgia filtrante para tratamento do glaucoma usualmente tem sucesso quando realizada precocemente, mas ela pode falhar devido à endotelização da fístula pela membrana anormal do endotélio corneano. O tratamento medicamentoso foi efetivo apesar da falha na trabeculectomia.

Descritores: Glaucoma; Doenças da córnea/diagnóstico; Doenças da íris/patologia; Endotélio corneano/patologia; Síndrome; Relato de casos

\footnotetext{
1 Ophthalmology Resident of Instituto de Olhos de Goiânia, Goiânia - Goiânia, GO, Brazil.

${ }^{2}$ Doctor, Department of Retina and Vitreous, Instituto de Olhos de Goiânia - Goiânia, GO, Brazil.

Study conducted at the Instituto de Olhos de Goiânia - Goiânia, GO, Brazil.

The authoes declare no conflicts of interests.

Received for publication 05/09/2012 - Accpted for publication 28/01/2013
} 


\section{INTRODUCTION}

$\mathbf{T}$ This study was conducted to describe a case of Cogan Reese syndrome, which is a rare disease classified as one of the variants of the iridocorneal endothelial syndrome, which affects young, healthy individuals and is not correlated to family history. The rapid evolution courses with persistent glaucoma ${ }^{(1,2)}$. It is often progressive, although it has already been reported the regression of a $\operatorname{case}^{(3)}$. The corneal abnormalities found are features such as polymorphism and endothelial polymegathism ${ }^{(2,4)}$. The specular microscopy shows pathognomonic endothelial alterations with the presence of abnormal cells, characterized by a dark area with a clear central spot and often a clear peripheral zone. The size of the cells varies, but typically they are larger than normal endothelial cells. They appear in areas that are presented with a metal aspect beaten to specular reflection at the slit lamp examination. They are called ICE-cells ${ }^{(2,5)}$. Some histological studies $^{(6)}$ and electron microscopy showed ectopic Descemet's membrane on the posterior corneal surface and before the iris, and the presence of cell necrosis and mild chronic inflammation, with loss of contact inhibition associated to the formation of multiple endothelial layers. These changes may or may not affect the entire endothelium ${ }^{(7,8)}$. Nodes representing spots of normal iris stroma surrounded by endothelial cells are characteristic, besides the iridian dystrophic changes such as atrophy, pseudopolycoria and uveal ectropion. This syndrome is rare and usually unilateral ${ }^{(2,9,10)}$

\section{Case Report}

Patient diagnosed with Cogan Reese syndrome in ophthalmological follow-up in the Eye Institute of Goiânia since February 2010. A.P.S., female, 55, from Paraúna - Goiás. The patient presented only hypertension under control as pathological background. Patient reports history of sudden low visual acuity (LVA) in the left eye (LE) held in July 2009. A trabeculectomy was performed in the LE 15 days after the episode of low visual acuity. Follow-up in this hospital began in February 2010. In November 2010 she was prescribed eyedrops of timolol maleate $0.5 \%$ and brimonidine tartrate $0.2 \%$ every 12 hours due to surgical treatment failure. A corneal specular microscopy was performed in June 2011, which showed the usual pattern in examination of the RE, and endothelial cell count decreased in the LE, as well as characteristic changes confirming the diagnosis of Cogan Reese Syndrome.

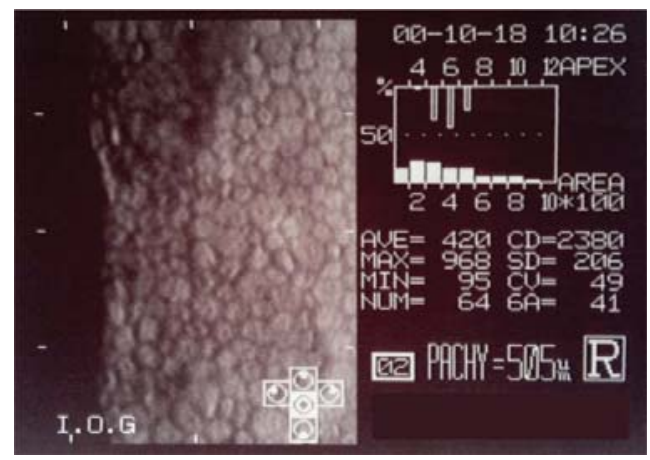

Figure 1 - Cell count within the usual pattern.

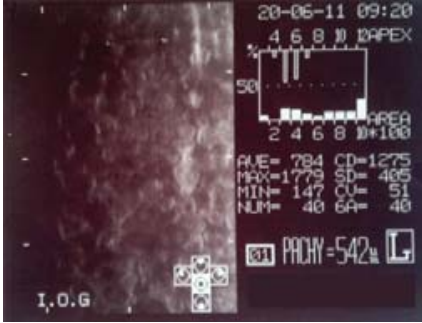

Figure 2 - Endothelial cell count decreased.

In March 2012 she was making use of the following eyedrops: dorzolamide hydrochloride $2 \%$ in the dosage of every 12 hours, timolol $0.5 \%$ every 12 hours, and brimonidine tartrate $0.2 \%$ every 12 hours in both eyes. The eye examination showed: visual acuity with best correction in right eye (RE) (+8.75): 20/30 and LE (+4.25 $\left.-1.5095^{\circ}\right): 20 / 100$. The biomicroscopy presented: in the RE - clear cornea, nuclear cataract $1+/ 4+$, wide anterior chamber, reagent pupil; and in the LE - cornea with central and peripheral discrete leukomas, diffuse superficial punctate keratitis, nuclear cataract 2$3+/ 4+$, non-reactive mydriasis, accessory pupil, nevus iridian.

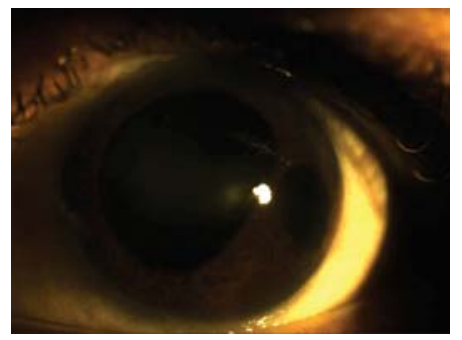

Figure 3 - Biomicroscopy evidencing accessory pupil.

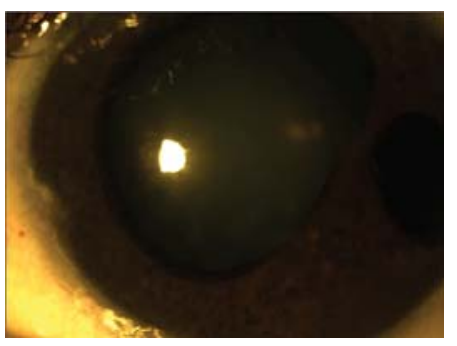

Figure 4 - Biomicroscopy evidencing nevus iridian and iris atrophy.

Gonioscopy of the left eye revealed high iris insertion, narrow angle and synechiae of 5 to 7 hours and 9 to 12 hours.

The eye fundus examination showed: RE - retinal applied, papillary excavation 0.5 , nerve with usual staining and aspect, retinal pigment epithelium in the usual pattern, vessels with normal path and size, macula with no visible changes

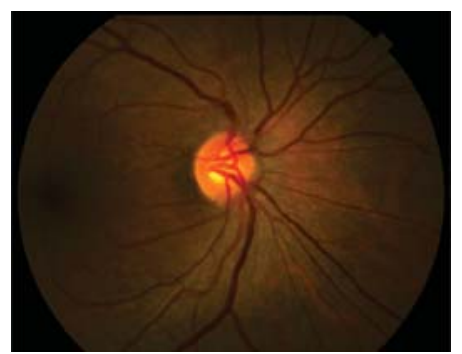

Figure 5 - Right eye fundus within the usual pattern. 
Eye fundus: LE - applied retina, papillary excavation 0.9 deep, slightly pale nerve, retinal pigment epithelium within the usual pattern, slightly tapered arteries in relation to the right eye, veins with usual path and size, macula with no visible changes.

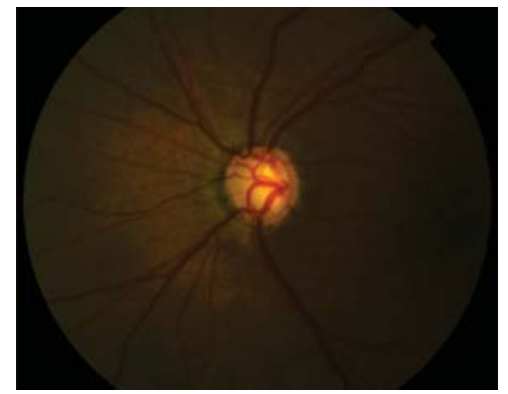

Figure 6 - Left eye fundus reveals excavation 0.9 with discreetly pale nerve in comparison to the right eye.

The intraocular pressure (IOP) was $11 \mathrm{mmHg}$ in the $\mathrm{RE}$ and $18 \mathrm{mmHg}$ in the LE. The visual field exam showed glaucomatous-type injury, and a progression was observed when compared to the same exams held in 2010,2011 and 2012. There was a reduction of sensitivity in the eye affected consistent with the damage caused by glaucoma in the left eye.

\section{Discussion}

Iridocorneal endothelial (ICE) syndrome is rare and predominant in leukodermic females with age of onset usually from the third decade of life $\mathrm{e}^{(3,9)}$. It is usually progressive and unilateral $^{(2,9-11)}$, and its etiology is attributed to chronic endothelial inflammation probably of viral etiology $\mathrm{y}^{(1,10,11)}$. Cogan Reese syndrome may present some degree of the characteristics present in other variants. However, its main finding is the nodules on the surface of the iris representing a remaining iris stroma surrounded by endothelial cells ${ }^{(8,9,11)}$. Multiple delayed goniosynechias extend in all directions, and may block the camerular sinus. Patients with Cogan Reese syndrome often complain of pupil changes ${ }^{(2)}$. It is believed that glaucoma is caused by the proliferation of corneal endothelium, with the formation of a membrane that progressively covers the trabecular meshwork, and not due to goniosynechias that emerge lately ${ }^{(1,4,11)}$.

The clinical treatment of glaucoma should be initially tried with agents that reduce the production of the aqueous humor, although many patients eventually need filtering surgery. Several filtering surgical procedures have been reported in the literature, with varied success in controlling eye pressure ${ }^{(2,9,12)}$. In the difficult cases of corneal edema, penetrating keratoplasty can be necessary after tension control ${ }^{(2,9)}$. The patient is with good clinical response to the treatment instituted, as it is common in some cases, particularly at the onset of the condition ${ }^{(1,9)}$.

The Medline database found 42 studies on Iridocorneal Syndrome, of which: 9 cases of surgical or drug failure, 5 cases of surgical success performed early, 1 case of drug failure, 2 cases of good control of intraocular pressure with iridotomy YAG laser, 1 successful case of filtering surgery after drug therapy failure, 24 cases of surgical success in the second filtration surgery carried out 2 years afterwards.

A case of Cogan Reese syndrome was reported, in which the patient presented corneal endothelium changes, iridian nodules, pseudopolycoria and secondary glaucoma. Early trabeculectomy was performed, there was an increase in the intraocular pressure two years afterwards, and currently reasonable pressure control is presented with the use of antiglaucoma eyedrops. The patient will be subjected to a new filtering surgery combined with facectomy with implantation of IOL.

Based on the results and the case discussed, it was concluded that knowledge of the syndrome and its prognosis are essential for its proper management. In case of failure of drug therapy, a filtering surgery shall be suggested before there is glaucomatous damage to the affected eye, since the disease is progressive with endothelial injury and risk of corneal decompensation.

This study aims to highlight the importance of the general ophthalmologist in identifying and better conducting rare and specific cases as the one described, since with early diagnostic and therapeutic it will be possible to decrease the morbidity of the syndrome.

\section{ACKNOWLEDGEMENT}

To Dr. João Jorge Nassaralla Junior for the methodological orientation.

\section{REFERENCES}

1. Wilson MC, Shields MB. A comparison of the clinical variations of the iridocorneal endothelial syndrome. Arch Ophthalmol. 1989;107(10):1465-8

2. Calixto N, Cronemberger S. Glaucoma e distrofias endoteliais corneanas. In: Almeida HG, Almeida GV, Calixto N, Carvalho CA. Glaucomas secundários. São Paulo: Roca; 1985. p. 291-8.

3. Bourne WM, Brubacker RF. Progression and regression of partial corneal involvement in the iridocorneal endothelial syndrome. Trans Am Ophthalmol Soc. 1992;90:201-19; discussion 219-24.

4. Alvarado JA, Murphy CG, Juster RP, Hetherington J. Pathogenesis of Chandler's syndrome, essential iris atrophy and the Cogan Reese syndrome. II. Estimated age at disease onset. Invest Ophthalmol Vis Sci. 1986;27(6):873-82.

5. Hirst LW, Quigley HA, Stark WJ, Shields NB. Specular microscopy of irido-corneal endothelial syndrome. Aust J Ophthalmol. 1980;8(2):139-46.

6. Khalil MK, Finlayson MH. Electron microscopy in iris nevus syndrome. Can J Ophthalmol. 1980;15(1):44-8.

7. Eagle RC Jr, Font RL, Yanoff M, Fine BS. The iris naevus (Cogan Reese) syndrome: light and electron microscopic observations. $\mathrm{Br}$ J Ophthalmol. 1980;64(6):446-52.

8. Radius RL, Herschler J. Histopathology in the iris-nevus (CoganReese) syndrome. Am J Ophthalmol. 1980;89(6):780-6.

9. Shields MB. Glaucoma associado a alterações primárias do endotélio corneano. In: Shields MB. Glaucoma. 2a ed. São Paulo: Panamericana; 1989. p. 235-45.

10. Huna R, Barak A, Melamed S. Bilateral iridocorneal endothelial syndrome presented as Cogan-Reese and Chandler's syndrome. J Glaucoma. 1996;5(1):60-2.

11. Laganowski HC, Sherrard ES, Muir MG, Buckley RJ. Distinguishing features of the iridocorneal endothelial syndrome and posterior polymorphous dystrophy: value of endothelial specular microscopy. Br J Ophthalmol. 1991;75(4):212-6. Comment in Br J Ophthalmol. 1993;77(9):610.

12. Kidd M, Hetherington J, Magee S. Surgical results in iridocorneal endothelial syndrome. Arch Ophthalmol. 1988;106(2):199-201.

\section{Corresponding author:}

Anelise de Medeiros LagoRua 19, número 90 apartamento 303 - Setor Oeste

ZIP Code: 74120-100 - Goiânia (GO), Brazil

Fax: (62) 32202557

E-mail: aneliselago@hotmail.com 